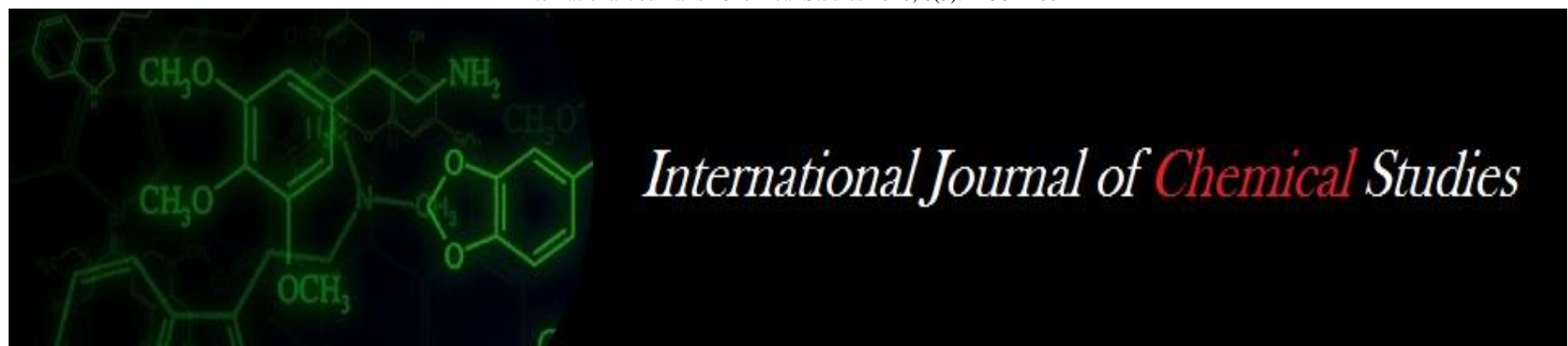

P-ISSN: 2349-8528

E-ISSN: 2321-4902

www.chemijournal.com

IJCS 2020; 8(5): 1458-1460

(C) 2020 IJCS

Received: 19-07-2020

Accepted: 29-08-2020

Kapil Bishnoi

College of Agriculture, Bikaner

Swami Keshwanand Rajasthan

Agricultural University, Bikaner,

Rajasthan, India

Vijay Prakash

ARS, Sriganganagar, Bikaner

Swami Keshwanand Rajasthan

Agricultural University, Bikaner,

Rajasthan, India
Corresponding Author:

Kapil Bishnoi

College of Agriculture, Bikaner

Swami Keshwanand Rajasthan

Agricultural University, Bikaner,

Rajasthan, India

\section{Genetic variability, heritability and genetic advance studies for yield and its contributing traits in clusterbean [Cyamopsis tetragonoloba $(\mathrm{L}$. Taub.].}

\section{Kapil Bishnoi and Vijay Prakash}

DOI: https://doi.org/10.22271/chemi.2020.v8.i5t.10507

\section{Abstract}

Forty diverse clusterbean genotypes were analyzed for genetic variability, heritability and genetic advance for yield and its contributing characters. The genotypes were significantly different for all the characters. High heritability along with high genetic advance (GA) as per cent of mean was recorded for number of branches/plant, biological yield/plant, seed yield/plant, number of clusters/plant and number of pods/plant indicating that these were controlled by additive gene effects and selection would be rewarding for these characters. The PCV estimates were invariably higher than their corresponding GCV values thereby suggesting the role of environmental influence. High estimates of GCV and PCV were observed for number of branches/plant, biological yield/plant, seed yield/plant, number of clusters/plant and number of pods/plant suggesting that selection based on these characters would facilitate successful isolation of desirable genotypes. The genotypes RGC 986, RARI-CB-18-25, HG 2-20, RGC 1017 and RARI-CB-18-20 were found promising having high mean performance for seed yield and other related traits.

Keywords: Variability, heritability, genetic advance and cluster bean

\section{Introduction}

Clusterbean is a drought tolerant, self-pollinated, leguminous crop belongs to family Fabaceae, commonly known as guar. India is a geographic center of variability for guar (Vavilov, 1951) ${ }^{[14]}$ while Gillet (1958) ${ }^{[4]}$ suggested that tropical Africa as its probable center of origin. It is an arid legume crop, mostly cultivated in the arid and semi-arid areas. Being a short duration crop, it holds immense potential to generate better economic returns to the growers from marginal land holdings with a huge production. Guar is mainly cultivated for food as vegetables, feed, fodder and guar gum. Its tender \& young pods are used as vegetables, which also known for cheap source of energy (16 Kcal), protein $(3.2 \mathrm{~g})$, carbohydrate $(10.8 \mathrm{~g})$, fat (1.4 g), vitamin A (65.3 IU), vitamin C (49 mg), calcium (57 mg) and iron (4.5 mg) for every $100 \mathrm{~g}$ of edible portion (Kumar and Singh, 2002). Leaves of guar are eaten to cure night blindness. Like other legumes, guar crop has the feature of formation of root nodules through which nitrogen fixing bacteria fixes about $30-40 \mathrm{~kg} \mathrm{~N} / \mathrm{ha}$. India is the largest producer with an area of 5.6 million hectares with production of 2.7 million tones and productivity $482 \mathrm{~kg} / \mathrm{ha}$ (Anonymous, 2017) ${ }^{[1]}$. Rajasthan holds first rank in area and production in India. In Rajasthan, it is cultivated on 3.08 million hectares area with the production of 1.03 million tones and productivity of $334 \mathrm{~kg} / \mathrm{ha}$ (Anonymous, 2019) ${ }^{[2]}$.

In any crop improvement programme, evaluation of genotype to assess the existing variability is considered as preliminary step. Variability for different traits in the source population is a prerequisite for crop improvement. Heritability is a good index of the transmission of character from parents to their offspring (Falconer, 1981) ${ }^{[3]}$. Heritability estimates coupled with genetic advance are generally more helpful in predicting the gain under selection rather than heritability estimates alone.

\section{Material and Method}

A field experiment was conducted at Research Farm, Swami Keshwanand Rajasthan Agricultural University, Bikaner during kharif 2019. 
Clusterbean germplasm comprising of 40 genotypes (Table 1) were evaluated in a randomized block design (RBD) with three replications. Each treatment was raised in $4 \mathrm{~m}$ long rows with spacing of $45 \mathrm{~cm}$ between rows and $30 \mathrm{~cm}$ between plants. The observations were recorded on the basis of five randomly selected plants from each replication for ten character viz., plant height, number of branches per plant, number of clusters per plant, number of pods per plant, number of seeds per pod, pod length, 100-seed weight, biological yield per plant, harvest index and seed yield/plant while days to $50 \%$ flowering and days to maturity were recorded on plot basis. The genetic variability, heritability and genetic advance were carried out as per standard procedures.

Table 1: Mean performance of clusterbean genotypes for different traits

\begin{tabular}{|c|c|c|c|c|c|c|c|c|c|c|c|c|c|}
\hline $\begin{array}{c}\text { S. } \\
\text { No. }\end{array}$ & $\begin{array}{l}\text { Name of } \\
\text { genotypes }\end{array}$ & \begin{tabular}{|c|} 
Day to \\
$50 \%$ \\
Flowering \\
\end{tabular} & $\begin{array}{c}\text { Plant } \\
\text { height } \\
\text { (cm) }\end{array}$ & \begin{tabular}{|c}
$\begin{array}{c}\text { Number of } \\
\text { branches/ } \\
\text { plant }\end{array}$ \\
\end{tabular} & \begin{tabular}{|c|}
$\begin{array}{c}\text { Number of } \\
\text { clusters/ } \\
\text { plant }\end{array}$ \\
\end{tabular} & \begin{tabular}{|c}
$\begin{array}{c}\text { Number } \\
\text { of pods/ } \\
\text { plant }\end{array}$ \\
\end{tabular} & $\begin{array}{c}\text { Number } \\
\text { of seeds/ } \\
\text { pod }\end{array}$ & \begin{tabular}{|c|} 
Pod \\
length \\
(cm) \\
\end{tabular} & $\begin{array}{c}\text { Day to } \\
\text { maturity }\end{array}$ & $\begin{array}{c}\begin{array}{c}100-\text {-seed } \\
\text { weight } \\
(\mathrm{g})\end{array} \\
\end{array}$ & \begin{tabular}{|c|}
$\begin{array}{c}\text { Biological } \\
\text { yield/plant } \\
\text { (g) }\end{array}$ \\
\end{tabular} & \begin{tabular}{|c|}
$\begin{array}{c}\text { Harvest } \\
\text { Index } \\
(\%)\end{array}$ \\
\end{tabular} & \begin{tabular}{|c|} 
Seed \\
yield/plant \\
(g)
\end{tabular} \\
\hline & RARI-CB-18-01 & 48.00 & 102.47 & 1.47 & 11.13 & 35.33 & 8.60 & 5.65 & 112.00 & 3.89 & 40.53 & 25.67 & 10.37 \\
\hline & RARI-CB-18-02 & 40.00 & 81.53 & 3.87 & 18.20 & 41.53 & 7.33 & 5.08 & 98.00 & 3.17 & 38.89 & 27.64 & 10.65 \\
\hline & RARI-CB-18-03 & 40.33 & 89.33 & 4.47 & 17.27 & 47.13 & 7.60 & 5.57 & 99.00 & 3.18 & 40.33 & 29.07 & 11.65 \\
\hline & RARI-CB-18-04 & 48.67 & 125.33 & 1.87 & 12.47 & 30.60 & 8.80 & 5.80 & 118.33 & 3.24 & 33.01 & 25.82 & 8.45 \\
\hline & RARI-CB-18-05 & 50.00 & 126.67 & 6.00 & 20.53 & 51.13 & 7.27 & 5.15 & 119.33 & 3.59 & 55.82 & 26.07 & 14.50 \\
\hline & RARI-CB-18-06 & 38.33 & 122.53 & 10.07 & 22.87 & 59.80 & 7.93 & 6.05 & 108.67 & 3.77 & 52.84 & 31.04 & 16.32 \\
\hline & RARI-CB-18-07 & 48.67 & 125.00 & 13.20 & 20.87 & 62.73 & 7.67 & 5.80 & 121.33 & 3.62 & 61.29 & 26.96 & 16.42 \\
\hline & RARI-CB-18-08 & 48.67 & 124.33 & 7.93 & 12.73 & 34.60 & 8.20 & 5.47 & 117.00 & 3.45 & 33.52 & 25.67 & 8.53 \\
\hline & RARI-CB-18-09 & 46.67 & 136.67 & 10.93 & 19.47 & 59.40 & 8.53 & 5.62 & 115.00 & 3.16 & 63.04 & 27.05 & 17.06 \\
\hline & RARI-CB-18-10 & 41.33 & 112.00 & 10.07 & 22.67 & 56.33 & 8.53 & 5.25 & 112.67 & 3.21 & 62.04 & 25.18 & 15.57 \\
\hline & RARI-CB-18-11 & 49.00 & 126.07 & 7.00 & 20.27 & 53.93 & 8.73 & 5.62 & 120.00 & 3.74 & 56.95 & 27.03 & 15.36 \\
\hline & RARI-CB-18-12 & 41.33 & 103.27 & 7.67 & 12.53 & 35.87 & 8.93 & 5.50 & 114.67 & 3.63 & 34.72 & 27.66 & 9.60 \\
\hline & RARI-CB-18-13 & 38.67 & 107.73 & 8.20 & 22.53 & 57.53 & 8.87 & 5.42 & 119.33 & 3.09 & 60.35 & 25.91 & 15.57 \\
\hline & RARI-CB-18-14 & 50.67 & 129.13 & 7.67 & 20.73 & 44.67 & 8.00 & 5.63 & 124.00 & 3.58 & 45.62 & 26.66 & 12.16 \\
\hline & RARI-CB-18-15 & 49.33 & 129.27 & 10.67 & 18.87 & 41.33 & 8.93 & 5.72 & 121.00 & 3.75 & 38.03 & 29.16 & 11.09 \\
\hline & RARI-CB-18-16 & 48.67 & 133.10 & 10.33 & 24.60 & 55.93 & 8.07 & 5.43 & .33 & 3.72 & 33 & 24.47 & 16.00 \\
\hline & RARI-CB-18-17 & 50.00 & 126.80 & 8.53 & 19.13 & 41.87 & 7.93 & 5.07 & 119.00 & 3.08 & 42.02 & 26.43 & 11.09 \\
\hline & RARI-CB-18-18 & 48.67 & 122.47 & 10.07 & 23.40 & 58.53 & 7.53 & 5.60 & 4.00 & 3.22 & 63.66 & 25.93 & 16.32 \\
\hline & RARI-CB-18-19 & 46.33 & 125.80 & & 23.20 & 61.20 & 7.80 & 5.50 & 122.00 & 3.80 & 55.77 & 31.27 & 17.41 \\
\hline & RARI-CB-18-20 & 47.00 & 122.80 & 9.73 & 24.20 & 76.13 & 8.80 & 5.93 & 122.67 & 3.32 & 70.47 & 25.96 & 18.16 \\
\hline & RARI-CB-18-21 & 47.00 & 110.80 & 1.40 & 12.40 & 63.87 & 7.67 & 5.73 & 110.67 & 3.77 & 48.40 & 26.72 & 12.80 \\
\hline & RARI-CB-18-22 & 45.67 & 93.80 & 7.33 & 22.07 & 35.07 & 8.47 & 5.57 & 109.33 & 3.32 & 35.41 & 25.09 & 8.89 \\
\hline & RARI-CB-18-23 & 48.00 & 86.20 & 7.87 & 11.20 & 57.93 & 8.00 & 5.59 & 111.33 & 3.23 & 55.08 & 28.74 & 15.78 \\
\hline & RARI-CB-18-24 & $\overline{00}$ & 47 & 0 & 17.87 & 48.07 & 7.73 & 5.19 & 67 & 3.82 & 34.71 & 31.55 & 10.88 \\
\hline & RARI-CB-18-25 & 46.33 & 95.53 & 9.00 & 25.87 & 65.07 & 8.27 & 5.47 & .00 & 3.66 & 75.14 & 26.15 & 19.51 \\
\hline & RARI-CB-18-26 & 51.67 & 115.93 & 7 & 24.07 & 57.73 & 7.60 & 5.25 & 67 & 3.76 & 58.25 & 26.85 & 15.36 \\
\hline & RARI-CB-18-27 & 7.33 & 114.60 & 33 & 26.00 & 56.87 & 8.40 & 5.55 & 120.33 & 3.75 & 60.40 & 27.36 & 16.44 \\
\hline & RARI-CB-18-28 & 47.33 & 111.60 & 6.60 & 17.40 & 50.27 & 8.00 & 5.67 & 121.33 & 3.27 & 40.97 & 30.64 & 12.48 \\
\hline & RARI-CB-18-29 & 50.67 & 106.73 & 7.73 & 16.93 & 44.07 & 7.47 & 5.27 & 118.67 & 2.99 & 41.58 & 26.48 & 10.88 \\
\hline & RARI-CB-18-30 & 46.67 & 115.60 & 8.73 & 24.07 & 55.33 & 8.53 & 5.30 & 123.00 & 3.73 & 51.65 & 31.22 & 16.00 \\
\hline & RGC 936 & 46.33 & 135.47 & 7.20 & 21.27 & 51.47 & 7.80 & 5.63 & 108.67 & 3.69 & 52.77 & 30.11 & 15.68 \\
\hline & RGC 1003 & 46.33 & 130.60 & 8.07 & 21.93 & 59.80 & 8.73 & 5.98 & 121.00 & 3.86 & 57.27 & 29.20 & 16.64 \\
\hline & RGC 1017 & 45.00 & 140.87 & 8.87 & 22.33 & 57.27 & 8.93 & 5.73 & 110.00 & 3.70 & 72.93 & 25.75 & 18.56 \\
\hline & RGC 1055 & 44.33 & 143.60 & 9.73 & 11.33 & 37.27 & 8.27 & 5.60 & 110.00 & 3.39 & 35.83 & 29.43 & 10.56 \\
\hline & RGC 1031 & 49.67 & 138.33 & 6.80 & 16.93 & 43.53 & 7.73 & 5.48 & 119.00 & 3.66 & 52.17 & 25.56 & 13.34 \\
\hline & RGC 1038 & 41.67 & 117.33 & 5.80 & 14.20 & 50.00 & 7.60 & 5.53 & 100.67 & 3.17 & 41.92 & 29.80 & 12.48 \\
\hline & RGC 1066 & 44.67 & 162.40 & 1.67 & 13.53 & 29.07 & 7.73 & 5.37 & 103.00 & 3.38 & 32.21 & 25.23 & 8.10 \\
\hline & RGC 986 & 49.33 & 136.93 & & 23.00 & 65.00 & 8.40 & 5.95 & 111.67 & 3.77 & 68.87 & 29.07 & 19.84 \\
\hline & & 40.67 & 124.80 & 1.20 & 14.07 & 30.53 & 8.73 & 7.55 & & 3.14 & 39.48 & 24.98 & 9.82 \\
\hline & HG-2-20 & 42.67 & 113.07 & 6.67 & 24.73 & 62.93 & 8.20 & 5.95 & 106.00 & 3.90 & 61.28 & 31.23 & 19.06 \\
\hline
\end{tabular}

\section{Results and Discussion}

The analysis of variance revealed that genotypes under study differed significantly for all the characters (Table 2). The data on general mean, range, the phenotypic (PV) and genotypic $(\mathrm{GV})$ variance, phenotypic (PCV) and genotypic (GCV) coefficients of variation, broad sense heritability (h2), genetic advance (GA) and genetic advance over mean (GAM) are presented in Table 3. PCV were higher than GCV for all the characters. This indicated the positive effect of environment in enhancing differences among genotypes at phenotypic level. High values of phenotypic and genotypic coefficient of variations were showed by number of branches/plant, number of clusters/plant, number of pods/plant, biological yield/plant and seeds yield per plant. These characters pointed out the presence of relatively high amount of genetic variability suggesting good scope for improvement by creating variability either by hybridization or mutation followed by selection. Moderate GCV and PCV was recorded for plant height while pod length and harvest index showed moderate
PCV but low GCV which suggests that improvement in these characters might be gained up to reasonable extent. The low GCV and PCV values were found for days to $50 \%$ flowering, number of seeds/pod, days to maturity and 100-seed weight. The heritability estimates in general were high $(>70 \%)$ for days to $50 \%$ flowering, plant height, number of branches/plant, number of pods/plant, number of clusters/plant, seed yield/plant, biological yield/plant and days to maturity. According to Panse and Sukhatme (1957) [10] such characters are governed pre-dominantly by additive gene action and could be improved through individual plant selection programme due to their high heritability values. These findings are in consonance with those of Kumar and Ram (2015) [7], Patil et al. (2016) [11], Santhosha et al. (2017) ${ }^{[13]}$, Rishitha et al. (2019) ${ }^{[12]}$ and Kgasudi et al. (2019) ${ }^{[6]}$.

The genetic advance (GA) is important in estimating the amount of progress that can be achieved by selecting for the particular trait. The expected genetic advance manifested as percentage of mean varied from 4.79 to 77.71 . High genetic 
advance were noticed for number of branches/plant, seed yield/plant, number of clusters/plant, biological yield/plant and number of pods/plant.

Heritability estimate generally affected by the type of genetic material, size of sample, sampling method, method of calculation and effect of linkage etc. Thus heritability values coupled with genetic advance would be more reliable and useful in predicting the gain under selection than heritability estimates alone. In the present study the traits like number of branches/plant, seed yield/plant, number of pods/plant, number of clusters/plant, biological yield/plant and plant height recorded high heritability accompanied with high genetic advance over mean indicated that genotypic variation in the material for these characters may possibly be due to high additive genetic variance, which show the possibility for high selection efficacy. These results are in conformity with the earlier findings of Muthuselvi and Shanthi (2013) [9], Malaghan et al. (2013) ${ }^{[8]}$ and Kapoor (2014) ${ }^{[5]}$.

Table 2: Analysis of variance for seed yield and other traits of clusterbean

\begin{tabular}{|c|c|c|c|c|c|c|c|c|c|c|c|c|c|}
\hline $\begin{array}{l}\text { Source of } \\
\text { variation }\end{array}$ & d.f. & \begin{tabular}{|c|} 
Day to \\
$50 \%$ \\
Flowering \\
\end{tabular} & $\begin{array}{c}\text { Plant } \\
\text { height } \\
(\mathbf{c m})\end{array}$ & \begin{tabular}{|c|}
$\begin{array}{c}\text { Number of } \\
\text { branches/ } \\
\text { plant }\end{array}$ \\
\end{tabular} & $\begin{array}{c}\text { Number of } \\
\text { clusters/ } \\
\text { plant } \\
\end{array}$ & $\begin{array}{c}\begin{array}{c}\text { Number } \\
\text { of pods/ } \\
\text { plant }\end{array} \\
\end{array}$ & $\begin{array}{l}\text { Number of } \\
\text { seeds/ pod }\end{array}$ & \begin{tabular}{|c|}
$\begin{array}{c}\text { Pod } \\
\text { length } \\
(\mathrm{cm})\end{array}$ \\
\end{tabular} & \begin{tabular}{|c|}
$\begin{array}{c}\text { Day to } \\
\text { maturi } \\
\text { ty }\end{array}$ \\
\end{tabular} & $\begin{array}{c}\text { 100-seed } \\
\text { weight } \\
(\mathrm{g}) \\
\end{array}$ & \begin{tabular}{|c|}
$\begin{array}{c}\text { Biological } \\
\text { yield/plant } \\
(\mathrm{g})\end{array}$ \\
\end{tabular} & $\begin{array}{c}\text { Harvest } \\
\text { Index } \\
(\%) \\
\end{array}$ & $\begin{array}{c}\text { Seed } \\
\text { yield/plant } \\
(\mathrm{g}) \\
\end{array}$ \\
\hline $\mathrm{R}$ & 2 & $0-6$ & 234.1 & 0.6 & 205 & 786 & ( & 0.41 & 3.66 & 801 & 1045 & 18.83 & \\
\hline & 39 & 37.9 & 882. & $24.73 * *$ & * & $k *$ & & $* *$ & $\begin{array}{c}153.86 \\
* *\end{array}$ & ** & $463.31 * *$ & $13.29 *$ & 3443 \\
\hline $\mathrm{rol}$ & \begin{tabular}{|l|}
78 \\
\end{tabular} & 3.97 & 0.39 & 44 & .04 & 18.27 & & 0.24 & 9.03 & 0.0 & 38. & 7.4 & 1.59 \\
\hline
\end{tabular}

$*$,** Significant at $5 \%$ and $1 \%$ respectively

Table 3: Estimates of genetic parameters of variation for 12 characters of clusterbean

\begin{tabular}{|c|c|c|c|c|c|c|c|c|}
\hline Characters & Mean & Range & $\begin{array}{c}\text { Genotypic } \\
\text { variance }\end{array}$ & $\begin{array}{l}\text { Phenotypic } \\
\text { variance }\end{array}$ & \begin{tabular}{|l|} 
Coefficient \\
Genotypic \\
\end{tabular} & \begin{tabular}{|l|} 
of variance \\
Phenotypic \\
\end{tabular} & $\begin{array}{c}\text { Heritability } \\
(\%)\end{array}$ & $\begin{array}{c}\text { G.A. as \% of } \\
\text { mean }\end{array}$ \\
\hline Days to $50 \%$ flowering & 46.24 & $38.33-51.66$ & 11.31 & 15.28 & 7.27 & 8.45 & 74.01 & 12.89 \\
\hline Plant height $(\mathrm{cm})$ & 118.97 & $81.53-162.40$ & 264.15 & 354.54 & 13.66 & 15.83 & 74.50 & 24.29 \\
\hline Number of branches/plant & 7.35 & $1.20-13.20$ & 8.10 & 8.54 & 38.74 & 39.78 & 94.83 & 77.71 \\
\hline Number of clusters/plant & 19.22 & $11.13-26.00$ & 19.95 & 22.99 & 23.24 & 24.95 & 86.77 & 44.59 \\
\hline Number of pods/plant & 50.67 & $29.07-76.13$ & 124.18 & 142.45 & 21.99 & 23.56 & 87.18 & 42.30 \\
\hline Pod length $(\mathrm{cm})$ & 5.61 & $5.07-7.55$ & 0.08 & 0.32 & 5.03 & 10.06 & 24.94 & 5.17 \\
\hline Number of seeds/pod & 8.16 & $7.27-8.93$ & 0.15 & 0.46 & 4.68 & 8.28 & 31.85 & 5.44 \\
\hline Days to maturity & 115.19 & $98.00-124.00$ & 48.28 & 57.31 & 6.03 & 6.57 & 84.24 & 11.40 \\
\hline 100 -seed weight $(\mathrm{g})$ & 3.50 & $2.99-3.90$ & 0.07 & 0.10 & 7.34 & 8.93 & 67.44 & 12.41 \\
\hline Biological yield/ plant $(\mathrm{g})$ & 50.76 & $32.21-75.14$ & 141.72 & 179.87 & 23.45 & 26.42 & 78.79 & 42.89 \\
\hline Harvest index $(\%)$ & 27.55 & $24.47-31.55$ & 1.96 & 9.38 & 5.08 & 11.12 & 20.89 & 4.79 \\
\hline Seed yield/plant $(\mathrm{g})$ & 13.88 & $8.10-19.84$ & 10.95 & 12.54 & 23.83 & 25.50 & 87.35 & 45.88 \\
\hline
\end{tabular}

\section{Conclusion}

Analysis of variance showed considerable amount of variability present among 40 genotypes for all the characters under study. Genotypes RGC 986, RARI-CB-18-25, HG 220, RGC 1017 and RARI-CB-18-20 substantially displayed higher mean values for seed yield/plant and other related traits. High GCV, PCV, high heritability with high genetic advance per cent mean was recorded for characters like number of branches/plant, number of clusters/plant, number of pods/plant, biological yield/plant and seed yield/plant indicated that these were controlled by additive gene effects.

\section{References}

1. Anonymous. Directorate of Economics \& Statistics, Department of Agriculture Cooperation and Farmers Welfare (DAC\&FW), 2017.

2. Anonymous. Final advance Estimate Rabi and Kharif 2018-19. Department of Agriculture, Rajasthan, 2019.

3. Falconer DS. Introduction to Quantitative Genetics, $2^{\text {nd }}$ ed. Longman, New York, 1981.

4. Gillet JB. Indigofera (microcharis) in tropical Africa with related genera Cyamopsis and Rhyncotropsis. Kew Bull. Add. Ser., 1958; 1:1-166.

5. Kapoor R. Genetic variability and association studies in guar [Cyamopsis tetragonoloba (L.) Taub.) For green fodder yield and quality traits. Electronic J. Plant Breeding. 2014; 5(2):294-299.

6. Kgasudi BK, Rekha GK, Jyothi KU, Sasikala K. Variability, heritability and genetic advance for yield and yield attributing characters in cluster bean [Cyamopsis tetragonoloba (L.) Taub.] Genotypes. Indian J Agri. Res., 2020; 54(2):247-251.
7. Kumar V, Ram RB. Genetic variability, correlation and path analysis for yield and yield attributing traits in cluster bean [Cyamopsis tetragonoloba (L.) Taub.] genotypes. Int. J Pure App. Biosci. 2015; 3(1):143-149.

8. Malaghan $\mathrm{SN}$, Madalageri MB, Ganiger VM, Bhuvaneshwari G, Patil HB, Kotikal YK. Analysis of genetic variability for seed yield and its component characters in cluster bean [Cyamopsis tetragonoloba (L.) Taub.]. Asian J Hort. 2013; 8(1):146-149.

9. Muthuselvi R, Shanthi A. Variability, heritability and genetic advance in clusterbean [Cyamopsis tetragonoloba (L.) Taub]. Advance Res. J Crop Improv. 2013; 4(2):106109.

10. Panse VG. Genetics of quantitative characters in relation to plant breeding. Indian J Genet. 1957; 17:318-328.

11. Patil BT, Bhalekar MN, Musmade AM, Shinde KG and Magar VG. Genetic variability and heritability studies in cluster bean (Cyamopsis Tetragonoloba L.). Bioinfolet A Quarterly J Life Sci. 2016; 13(2a):247-250.

12. Rishitha G, Rajya Lakshmi R, Uma Jyothi K, Uma Krishna K. Studies on genetic variability, heritability and genetic advance for yield and yield attributing characters in cluster bean [Cyamopsis tetragonoloba (L.) Taub.]. Int. J Curr. Microbiol. App. Sci. 2019; 8(08):1307- 1312.

13. Santhosha GR, Shashikanth E, Gasti VD, Prabhuling G, Rathod VD, Mulge R. Genetic variability studies in cluster bean [Cyamopsis tetragonaloba (L.) Taub.] for growth, yield and quality parameters. Legume Res. 2017; 40(2):232-236.

14. Vavilov NI. The origin, variation, immunity and breeding of cultivated plants. Chronica Botanica, 1951, 13. 